\title{
Effect of Lead Exposure on the Activity of Some Hepatic Enzymes in the Rat
}

\author{
GABRIEL DINARI, MICHAEL I. COHEN ${ }^{(38)}$ HELEN MCNAMARA, AND JOSEPH A. KOCHEN
}

Divisions of Adolescent Medicine and Hematology and the Pediatric Gastrointestinal and Liver Disease Service, Department of Pediatrics, Montefiore Hospital and Medical Center and the Albert Einstein College of Medicine, Bronx, New York, USA

\section{Summary}

Seven-day-old rats were fed $1 \%$ lead acetate tetrahydrate solution for 2, 4, or 7 days. Adult rats were fed the same lead solution for 6-8 wk. In the newborn rats, hepatic UDP-bilirubin glucuronyl transferase (GT) and gamma glutamyl transpeptidase (GGTP) activities were markedly increased. GT activity was increased after 4 days as compared to the controls $(6.3 \pm 0.3$ vs. $4.3 \pm 0.3$, $P<0.001)$, and was maximal after 7 days of treatment $(7.5 \pm 0.4$ vs. $4.6 \pm 0.4, P<0.001)$. GGTP activity was already maximally increased after 2 days of lead treatment $(1.4 \pm 0.2$ vs. $0.4 \pm 0.1, P$ $<0.001$ ). Hepatic GT and GGTP activities were similarly increased in adult rats $(7.9 \pm 0.3$ vs. $5.1 \pm 0.1, P<0.001$, and 0.7 \pm 0.1 vs. $0.4 \pm 0.1, P<0.005$, respectively). In vitro studies adding lead citrate to liver homogenates did not produce any direct effect on GT and GGTP activities.

\section{Speculation}

The increase in hepatic GT and GGTP activities in lead treated animals appears to be a response to lead induced cellular damage or may result from interference with regulatory mechanisms responsible for production of these enzymes and not related to hepatic enzyme induction. The hepatic metabolism of drugs ingested by children with an increased lead burden may, therefore, be significantly altered.

While lead remains one of the more important industrial and environmental toxins, and a series of recent factors have reduced the incidence of lead exposure and toxicity (11), its affect on the liver has received relatively little attention when compared to its impact on hematopoietic and neuromuscular systems. Lead administration to animals causes changes in the liver $(12,14)$ visible by light and electron microscopy. Additionally, it increases the concentrations of enzymes in serum released from damaged hepatocytes, and produces alterations in hepatocyte function as manifested by decreased bilirubin clearance and enhanced bromosulfophthalein retention $(8,31)$. Recently, inhibition of the microsomal hepatic cytochrome P-450 dependent mixed function oxidase system has been reported $(3,26)$ in lead intoxicated animals and humans, suggesting the possibility of an alteration in hepatic drug metabolism. In order to explore further the effects of lead on hepatic enzyme activity, microsomal, noncytochrome P-450 dependent systems were studied in rats previously shown to be poisoned by lead (17).

\section{MATERIALS AND METHODS}

\section{ACUTE NEONATAL EXPOSURE}

Seven-day-old Sprague Dawley breast-feeding rat pups were fed $0.5 \mathrm{ml}$ of a $1 \%$ lead acetate tetrahydrate solution by oral gastric tube daily for 2,4 , or 7 days. Littermates were used as controls and given $0.5 \mathrm{ml}$ of $0.9 \%$ saline. The number of lead treated animals and littermate controls at 2,4 , and 7 days were 12,$10 ; 8$, 6 ; and 20,18 , respectively. All animals were killed by decapitation $24 \mathrm{hr}$ after the last dose. The livers were removed, weighed, and the activity of UDP-bilirubin GT (EC 2.4.1.17), GGTP (EC 2.3.2.2), and hepatic protein content were determined.

\section{CHRONIC ADULT EXPOSURE}

Fifteen adult male Sprague Dawley rats weighing 200-250 g were given a $1 \%$ lead acetate tetrahydrate solution in their daily drinking water for 6-8 wk. The lead solution was offered ad libitum. At the end of the treatment period, the rats were killed by decapitation, the livers were removed, weighed, GT and GGTP activities measured, and protein concentrations determined. Eighteen adult rats served as a control group receiving a standard rat chow and untreated drinking water ad libitum.

\section{IN VITRO EXPOSURE}

In the determination of GT, digitonin is used to alter membrane configuration and "unmask" active enzyme sites (6). In order to determine the effect, if any, of lead acetate on microsomal membrane function and, therefore, on GT activity, this enzyme activity was measured in liver homogenates from six control rats and six adult rats treated with lead for $8 \mathrm{wk}$, with and without digitonin added. Additionally, GT activity was determined in liver homogenates from five adult control rats to which 0.02 or $0.05 \mathrm{ml}$ of $1 \%$ lead acetate tetrahydrate was added just before the incubation procedure. In three of these homogenates, hepatic GGTP activity was also determined.

In all experiments, portions of the removed liver were washed in cooled $0.154 \mathrm{M} \mathrm{KCl}, \mathrm{pH} 7.4$ or $0.1 \mathrm{M}$ Tris buffer, $\mathrm{pH} 9.5$ for GT and GGTP determinations, respectively, and homogenized by an electrically driven plastic pestle. Hepatic bilirubin glucuronyl transferase activity was determined using the method of Black and Billing. (6), and a modification of the method of DeLeon et al. (9). This modification consisted of the addition of $2 \%$ digitonin in $0.154 \mathrm{M} \mathrm{KCl}$ added to a $10 \%$ liver homogenate in a 1:1 dilution just before the addition of $0.1 \mathrm{ml}$ of UDP glucuronic acid $(6.6 \times$ $\left.10^{-2} \mathrm{M}\right)$. The results were expressed as $\mu \mathrm{g}$ of bilirubin conjugated per $\mathrm{mg}$ of liver protein per $40 \mathrm{~min}$.

Hepatic GGTP activity was determined using the method of Orlowski and Meister (21) as modified in our laboratory (7). The results were expressed as $\mu \mathrm{g}$ of $\beta$-naphthylamine formed per $\mathrm{mg}$ of liver protein per $30 \mathrm{~min}$.

Liver protein content was measured by the method of Lowry et al. (18), and expressed as mg of protein per gram of liver.

Statistical evaluation consisted of Student's $t$ test.

\section{RESULTS}

\section{ACUTE NEONATAL EXPOSURE}

Oral lead acetate administration to neonatal animals was found to induce hepatic GT and GGTP activities (Table 1). Although a 
Table 1. Hepatic UDP-bilirubin GT and GGTP activities in 7-day-old rats treated with $1 \%$ lead acetate tetrahydrate solution for a 2-4- or 7-day period; and in adult rats treated with the same solution for 6-8 wk. Number of animals is in parentheses. Results are expressed as the mean $\pm 1 S E$.

\begin{tabular}{|c|c|c|c|c|c|c|c|c|}
\hline & \multicolumn{6}{|c|}{ Newborn } & \multicolumn{2}{|c|}{ Adult } \\
\hline & Control (10) & $\begin{array}{c}\text { Treated, } \\
2 \text { days } \\
\text { (12) }\end{array}$ & Control (6) & $\begin{array}{c}\text { Treated, } \\
4 \text { days } \\
(8)\end{array}$ & Control (18) & $\begin{array}{c}\text { Treated, } \\
7 \text { days } \\
(20)\end{array}$ & Control (18) & $\begin{array}{l}\text { Treated, 6-8 } \\
\quad \text { wk (15) }\end{array}$ \\
\hline \multirow[t]{2}{*}{$\mathrm{GT}(\mu \mathrm{g} / \mathrm{mg}$ protein) } & $4.21 \pm 0.38$ & $4.05 \pm 0.35$ & $4.26 \pm 0.33$ & $6.31 \pm 0.29$ & $4.62 \pm 0.37$ & $7.52 \pm 0.42$ & $5.11 \pm 0.13$ & $7.92 \pm 0.34$ \\
\hline & \multicolumn{2}{|c|}{ (NS) } & \multicolumn{2}{|c|}{$(P<0.001)$} & \multicolumn{2}{|c|}{$(P<0.001)$} & \multicolumn{2}{|c|}{$(P<0.001)$} \\
\hline GGTP $(\mu \mathrm{g} / \mathrm{mg}$ protein) & \multicolumn{2}{|c|}{$(P<0.001)$} & $\begin{array}{r}0.31 \pm 0.02 \\
(P<\end{array}$ & $\begin{array}{l}1.58 \pm 0.22 \\
001)\end{array}$ & $\begin{array}{r}0.26 \pm 0.03 \\
(P<\end{array}$ & $\begin{array}{l}1.66 \pm 0.3 \\
.001)\end{array}$ & $\begin{array}{r}0.36 \pm 0.05 \\
(P<\end{array}$ & $\begin{array}{l}0.73 \pm 0.12 \\
.005)\end{array}$ \\
\hline
\end{tabular}

Table 2. Hepatic UDP-bilirubin glucuronyl transferase activity, expressed as $\mu \mathrm{g} / \mathrm{mg}$ protein, in liver homogenates from 6 control and 6 lead treated adult rats, with and without digitonin added to the reaction mixture. Results are expressed as the mean $\pm 1 S E$.

\begin{tabular}{lcc}
\hline & No digitonin added & With digitonin added \\
\hline Control & $2.10 \pm 0.26$ & $4.79 \pm 0.26$ \\
& & \\
Lead treated & $2.29 \pm 0.46$ & $6.45 \pm 0.71$ \\
& NS & $P<0.001$ \\
\hline
\end{tabular}

2-day period of exposure failed to demonstrate any effect, 4 days of treatment demonstrated a significant increase in GT activity over control animals $(P<0.001)$, with a further increase noted after 7 days $(P<0.05)$. Alternatively, hepatic GGTP activity was significantly increased $(P<0.001)$ after only 2 days of lead treatment, and no further increases were found after 4 and 7 days of lead ingestion. There were no changes in liver protein concentrations noted.

\section{CHRONIC ADULT EXPOSURE}

Hepatic GT and GGTP activities in chronically lead treated adult rats were significantly increased over control animals $(P<$ 0.001 and $P<0.005$, respectively) and similar to the findings demonstrated in the neonatal rat (Table 1). Hepatic protein concentrations remained unchanged between lead treated and control rats.

\section{IN VITRO EXPOSURE}

No differences in hepatic GT activities were found when homogenates from lead treated and control animals were assayed in the absence of digitonin. However, when digitonin was added to the reaction mixture, the expected increase in GT activity $(P<$ $0.001)$ was appreciated in the liver homogenates from the lead treated rats (Table 2). The addition of lead acetate to the reaction mixture of liver homogenates from animals never exposed to lead failed to demonstrate any significant changes in GT and GGTP activities.

\section{DISCUSSION}

After absorption, lead is found initially in erythrocytes, liver and kidney and is ultimately stored in the bone (14). Appreciable amounts have been localized in nuclear, mitochondrial, lysosomal, microsomal, and soluble cellular subfractions of rat liver (4). Ultrastructural changes in liver have included intranuclear inclusion bodies (12), vacuolization, the presence of granular electron dense material, degenerative changes in Kupffer cells and hepatocytes, and proliferation of endoplasmic reticulum (14). Lead has a strong affinity for mitochondria and is bound to the mitochondrial membrane producing swelling, lamellar bodies, and a reduced number of crystae $(12,34)$.

In addition to these morphologic changes, lead administration produces functional alterations including the suppression of cellular respiration, and the inhibition of oxidation-reduction reac- tions and glycolysis (8). Among the more profound effects of lead is its influence on enzyme activity. The activities of many enzymes are inhibited by lead and a partial list includes: $\delta$-aminolevulinic acid dehydratase and heme synthetase (8), erythrocytic membrane (13), and intestinal mucosal $\left(\mathrm{Na}^{+}, \mathrm{K}^{+}\right)$ATPase (33), erythrocytic pyrimidine specific 5-nucleotidase (22), renal malate dehydrogenase, glutamate dehydrogenase (16), acetylcholine esterase (10), intestinal alkaline phosphatase, and liver, and renal acid phosphatase (30).

However, the serum activities of some enzymes may be increased in association with lead intoxication and this is believed due to tissue damage and release of enzyme into the blood. Hepatic injury has been thought to be the cause of the observed increase in serum levels of serum glutamic oxalacetic transaminase, serum glutamic pyruvic transaminase, alkaline phosphatase, aldolase, as well as other cytoplasmic and mitochondrial enzymes $(8,21,31)$.

The mechanism by which lead causes the structural damage and affects enzyme activity is not well understood. Heavy metals are capable of combining with a variety of organic molecules and interacting with sulfhydryl, carboxyl, amino and phosphoryl groups (23). Lead may cause direct inhibition of enzymatic activity by such interactions $(16,32)$, although decreased synthesis of enzymes has also been suggested (25). An attempt at further clarification of the effects of lead on enzymatic activity is noted in recent studies of hepatic biotransformation of drugs, hormones, and other chemicals mediated through the mixed function oxidase system in the liver.

A substantial portion of heme synthesized in the liver serves as a prosthetic group for the microsomal hemoprotein, cytochrome $\mathrm{P}-450$, the terminal oxidase of the mixed function oxidase system. It would appear, that just as lead impairs heme synthesis in the erythrocyte, it may also impair hepatic cytochrome P-450 synthesis, and, thus, interfere with drug metabolism $(3,26)$. Alvarez et al. $(1,3)$ obtained inhibition of hepatic mixed function oxidase in animals by parenteral lead administration, with an increase in hexobarbital sleeping time. Similar results were obtained by Scoppa et al. (27), who found. a correlation between altered drug metabolism and inhibition of blood and liver $\delta$-aminolevulinic acid dehydratase by lead. However, oral administration of lead did not inhibit microsomal oxidative enzymes in animals $(1,5,24$, 26 ), or phenobarbital induced microsomal heme synthesis (2). Additionally, there was no effect on the half-life of antipyrine and phenylbutazone in lead poisoned human subjects $(1,2)$. The reasons for the discrepancies between the enzymatic effects of parenteral and oral lead administration are not clear. Explanations include: the animal model employed, the dose absorbed, nutritional influences, or a combination of these, as well as other, as yet undetermined factors (5).

The study reported herein explored the effects of intestinal lead absorption on two microsomal liver enzyme activities which are not cytochrome P-450 dependent. The demonstrated increase in activity of hepatic GT and GGTP is at variance with the usual inhibitory effect of lead administration on tissue enzyme activities. It is important to note that the effect is rapid as demonstrated by the acute exposure experiment and occurs in both neonatal and 
adult animals. In a few studies, enzymatic induction by lead has been demonstrated. Howard (15) found increased erythrocytic glutathione reductase activity in lead exposed human subjects, and postulated that the increase is a compensatory mechanism and due to the removal of reduced glutathione. Secchi et al. (28) found an increase in guinea pig renal lactate dehydrogenase (isoenzymes 4 and 5) and glucose 6 phosphate dehydrogenase activity after oral lead treatment. This pattern was identical to the enzymatic changes noted after experimental renal ischemia. These latter results were interpreted as indicating a metabolic adaptation of the kidney to tissue hypoxia.

The previously described effects of lead on mitochondria and cellular respiration (12) lend credence to the hypothesis that an increase in enzyme activity is a compensatory response to lead provoked cellular respiratory failure. Although our data demonstrate increased tissue enzyme activity in lead treated animals, no difference in hepatic protein concentrations was observed. This argues against an induction phenomenon which is usually associated with increased protein synthesis.

Recent data suggest that GT may be activated in vitro by pretreatment of the microsomal enzyme preparation using detergents or sonication, thus, affecting membrane structure or conformation and unmasking active sites $(19,35)$. Our use of digitonin in liver homogenates from lead pretreated and nontreated rats does not support this hypothesis as an explanation of the observed results. The increase in GT and GGTP activity does not appear to be caused by a direct effect of lead on membrane configuration. If lead had a direct membrane effect, we might have observed an increase in GT activity in liver homogenates from lead treated animals as compared to controls, when the determination was performed without digitonin. Furthermore, some change in measured activity might have been expected when varying amounts of lead were incubated with the homogenate and this was not observed.

Additional support for the lack of a membrane effect of lead derives from reports that the in vitro addition of lead to liver microsomes did not show any effect on mixed function oxidase activities $(26,27)$.

Although orally administered lead rapidly increases both GT and GGTP activity in neonatal and adult rat hepatic tissue, the exact mechanism remains unclear. As yet unexplained cellular respiratory damage rather than changes in membrane configuration and/or enzyme induction appears to be a more likely etiologic hypothesis. Alternatively, lead may bind to or interfere with some inhibitory substances that regulate the production of these enzymes. The toxicologic significance of these findings is difficult to assess, because the administered dose of lead was relatively high when compared to the usual environmental exposure in childhood. However, these experimental data suggest that the metabolism of various drugs offered to children with excessive lead exposure and/or an increased lead burden may be altered.

\section{REFERENCES AND NOTES}

1. Alvarez, A. P., Fischbein, A., Sassa. S., Anderson, K. E., and Kappas, A.: Lead intoxication: effects on cytochrome P-450 mediated hepatic oxidations. Clin. Pharmacol. Ther., 19: 183 (1976)

2. Alvarez, A. P., Kapelner, S., Sassa, S., and Kappas, A.: Drug metabolism in normal children, lead poisoned children, and normal adults. Clin. Pharmacol. Ther., 17: 179 (1975).

3. Alvarez, A. P., Leigh, S., Cohn, J., and Kappas, A.: Lead and methyl mercury: effects of acute exposure on cytochrome P-450 and the mixed function oxidase system in the liver. J. Exp. Med., I35: 1406 (1972).

4. Barltrop, D., Barrett, A. J., and Dingle, J. T.: Subcellular distribution of lead in the rat. J. Lab. Clin. Med., 77: 705 (1971).

5. Becking, G. C.: Trace elements and drug metabolism. Med. Clin. N. Am., 60: 813 (1976).
6. Black, M., and Billing, B. H.: Hepatic bilirubin UDP-glucuronyl transferase activity in liver disease and Gilbert's syndrome. N. Engl. J. Med., 280: 1266 (1969).

7. Cohen, M. I., Gartner, L. M., Blumenfeld, O. O., and Arias, I. M.: Gamma glutamyl transpeptidase: measurement and development in guinea pig small intestine. Pediatr. Res., 3: 5 (1969).

8. DeBruin, A.: Certain biological effects of lead upon the animal organism. Arch. Environ. Health, 23: 249 (1971).

9. DeLeon, A., Gartner, L. M., and Arias, I. M.: The effect of phenobarbital on hyperbilirubinemia in glucuronyl transferase deficient rats. J. Lab. Clin. Med., 70: 273 (1967).

10. Galzigna, L., Ferraro, M. W., Manani, G. and Viola, A.: Biochemical basis for the toxic effects of triethyl lead. Br. J. Ind. Med., 30: 129 (1973):

11. Goldberg, A.: Review of recent advances of lead in clinical research. Postgrad. Med. J., s1: 747 (1975).

12. Goyer, R. A., and Rhyne, B. C.: Pathological effects of lead. Int. Rev. Exper. Pathol., 12: 1 (1973).

13. Hassan, J., Vihko, V., and Hernberg, S.: Deficient red cell membrane $\left(\mathrm{Na}^{+}-\mathrm{K}^{+}\right)$ - ATPase in lead poisoning. Arch. Environ. Health, 14: 313 (1967).

14. Hoffmann, E. O., DiLuzio, N. R., Holper, K., Brettschneider, L., and Coover, J. Ultrastructural changes in the liver of baboons following lead and endotoxin administration. Lab. Invest., 30: 311 (1974).

15. Howard. J. K.: Human erythrocyte glutathione reductase and glucose 6-phosphate dehydrogenase activities in normal subjects and in persons exposed to lead. Clin. Scien. Mol. Med., 47: 515 (1974).

16. Iannaccone, A., Boscolo, P., and Bombardieri, G.: Comparative effects of experimental lead poisoning on enzymatic activities of kidney and liver in rat. Life Sci., 19: 424 (1976).

17. Kochen, J. A., Muller-Eberhard, U., Cohen, M. I., Dinari, G., Greener, Y.: Metabolic effects of lead in newborn rats. Pediatr. Res., 11: 417 (1977).

18. Lowry, O. H., Rosebrough, N. J., Farr, A. L., and Randa, R. J.: Protein measurements with the Folin-Phenol reagent. J. Biol. Chem., 193: 265 (1951)

19. Mulder, G. J.: On non-specific inhibition of rat liver microsomal UDP Glucuronyl transferase by some drugs. Biochem. Pharmacol., 23: 1283 (1974).

20. Norpoth, K., Ho, S., and Witting, U.: Induction of microsomal hemoproteids in the liver of rats after ingestion of inorganic lead compounds. Int. Arch. Arbeitsmed., 33: 139 (1974).

21. Orlowski, M., and Meister, A.: Gamma-glutamyl-P-nitroanillide: A new convenient substrate for determination and study of L- and D-gamma-glutamyltranspeptidase activities. Biochem. Biophys. Acta, 73: 679 (1963).

22. Paglia, D. E., Valentine, W. N., and Dahlgren, J. G.: Effects of low-level lead exposure on pyrimidine 5-nucleotidase. J. Clin. Invest. 56: 1164 (1975).

23. Passow, H., Rothstein, A., and Clarkson, T. W.: The general pharmacology of the heavy metals. Pharmacol. Rev., 13: 185 (1961).

24. Phillips, W. E. J., Villeneuve, D. C., and Becking, G. C.: The effects of lead ingestion on the body burden of DDT, liver vitamin A and microsomal enzyme activity in the rat. Bul. Environ. Contam. Toxicol., 6: 570 (1971).

25. Rhyne, B. C., and Goyer, A. A.: Cytochrome content of kidney mitochondria in experimental lead poisoning. Exp. Mol. Pathol., 14: 386 (1971).

26. Ribeiro, H. A.: Effects of certain metal ions on hepatic microsomal enzymes. Proc. West. Pharmacol. Soc., 13: 13 (1970).

27. Scoppa, P., Roumengous, M., and Penning, W.: Hepatic drug metabolizing activity in lead poisoned rats. Experientia, 29: 970 (1973).

28. Secchi, G. C., Alessio, L., and Cirla, A.: The effect of experimental lead poisoning on some enzymatic activities of the kidney. Clin. Chim. Acta, 27: 467 (1970).

29. Secchi, G. C., Alessio, L., and Spreafico, E.: Serum enzymatic activities in experimental lead poisoning. Enzyme, 12: 63 (1971).

30. Sroczynski, J. and Zajusz, K.: Histoenzymatic reaction in experimental lead poisoning in rabbits. Arch. Immun. Therap. Exp., 14: 391 (1966).

31. Trejo, R. A., DiLuzio, N. R., Loose, L. D., and Hoffman, E.: Reticuloendothelial and hepatic functional alterations following lead acetate administration. Exp. Mol. Pathol., 17: 145 (1972).

32. Vallee, B. L., and Ulmer, D. D.: Biochemical effects of mercury, cadmium and lead. Ann. Rev. Biochem., 41: 91 (1972).

33. Wapnier, R. A., Exeni, R. A., McVicar, M., and Lifshitz, E.: Experimental lead poisoning and intestinal transport of glucose, amino acids, and sodium. Pediatr. Res., 11: 153 (1977).

34. Watrach, A. M.: Degeneration of mitochondria in lead poisoning. J. Ultrast. Res., 10: 177 (1964).

35. Wisnes, A.: Age and sex dependent variability of the activation characteristics of UDP-Glucuronyltransferase in vitro. Biochem. Pharmacol., 20: 1249 (1971).

36. The authors thank Ygal Greener, Ph.D. for technical assistance.

37. This research was supported, in part, by the Joseph C. and Claire F. Goodman Pediatric Gastroenterology Research Fund and by the National Foundation March of Dimes.

38. Requests for reprints should be addressed to: Michael I. Cohen, Department of Pediatrics, Montefiore Hospital and Medical Center, 111 East 210 Street, Bronx, New York 10467, USA.

39. Received for publication March 28, 1978.

40. Accepted for publication June 15, 1978. 